UDC 316.3:32.001

Manuk HARUTYUNYAN

\title{
ARMENIAN ALIENATED SOCIETY: FROM DIAGNOSIS TO ACTION
}

\begin{abstract}
The article in concentrated form, presented our monographic work "the Modern Armenian society and the philosophy of alienated consciousness." The study shows that the alienation is of systemic nature. The mood of alienation is inherent not only to the legislative, executive and judicial authorities but also political parties, public organizations, mass media, and electoral system.

The article may be of interest to specialists in problems of alienation, undergraduates, graduate students and teachers of humanitarian higher educational establishments.
\end{abstract}

Keywords: alienation, political alienation, political corruption, modernization, social justice.

While discussing the intention of designing a model of the national-democratic modernization of the Armenian society, we should all the time keep in mind an extremely negative experience of reforming our country. That experience was not in line with our historical traditions, with the character of the Armenian nation and with the real development of economic and political institutions.

The realization is growing that one of the underlying causes of the national catastrophe or the greatest damage brought about in Armenia and in other post-Soviet societies was a vulgar and inept use of the liberal idea of economic modernization according to the methods borrowed or merely transferred from the existing Western economic institutions without the analysis of one's own historical and problems context. The analysis of what and how has been done makes it incumbent to re-examine the history of the illness and to look for the causes of earlier mistakes. It means that all attempts at circumventing and at not taking into consideration the specific problems of the country's development, merely setting hopes in a childish way on ill-advised perceptions of the universality of the Western concept of the "catch-up modernization," were not only unsubstantiated but also had disastrous consequences. Secondly, in the 1990s the choice of concrete models for subsequent development of economies of Armenia and other post-Soviet countries was not predetermined in advance. To make a right choice it was necessary to identify the specific problems of the country's economy and to compare them with the problems that had already been addressed in the works of the sociologists from the eastern European and CIS countries. That would have allowed to use their recommendations and to assess the sociologists' warnings and to take a closer look at the projects to modernize economy that had already been carried out. Their understanding would have made it possible to learn useful, albeit bitter for national selfesteem lessons and to draw necessary conclu- 
sions thereby holding us back from embarking on a reckless path of experimentation that was so dangerous for the nation. Thirdly, the postSoviet megalomaniac "reformers", the likes of Gaidar, Bagratian, etc., did not even pause to think about the causes of successful functioning of democratic institutions in the place of their origin and under different societal circumstances. They did not or would not contemplate social or political risks and dangers related to economic determinism and did not realize that a dramatic turn to a fruitful strategy of economic modernization was never an easy undertaking. Taking guidance from Gaidar's precepts, the "reformers" from the PanArmenian National Movement (PANM), including younger generation Gaidar follower Hrant Bagratian, were confident that the design and use of a market economy mechanism was more important than making the human factor more active. They thought naively that if that mechanism is put into operation, then ordinary Armenians will adjust their behavior to the requirements of economic mechanisms. However, it was found out that there were no grounds to assume that ordinary Armenians would easily and gladly get adjusted to the requirements of the market "mechanism" and would also easily give up their social values. The "reformers" failed to realize that ordinary Armenians do not adjust their everyday economic behavior to the precepts of the newlyfledged holders of Ph.D. in economics. The matter concerns here primarily the fact that social ills are triggered not from some place above but by acting institutions and individuals. Consequently, the current situation, say, in the Armenian economy is not the result of interference of some outside forces or objective circumstances but is a result of activities of concrete persons, first of all persons endowed with power or involved in power structures and who therefore bear political responsibility for the outcome of those activities. From this perspective, the persistent assurances voiced by notorious "reformer" $\mathrm{H}$. Bagratian that that he allegedly "did not impose any model on anyone" at the initial stage of privatization in Armenia sound at least strange.

If we turn to the logic of facts, his claims tumble down as a house of cards. The land privatization that was carried out in Armenia based on the 1991 law on privatization of land not only was accompanied by flagrant violations of peasants' socioeconomic rights, by the lack of the State support and of private investments but also by the restoration of ancient, archaic forms of farming that looked very much like the subsistence economy of the feudal times. That led to almost total alienation of rural population from the State and its "reformist" economic policies and, eventually, to a mass exodus of Armenians from rural areas. The voucher privatization resulted, on the one hand, in the formation of a narrow social group of very wealthy people, and, on the other hand, to pauperization, i.e. impoverishment of the population across the board. Privatization in Armenia pursued one goal only, viz. to transfer quickly the State-owned, public property into private hands to the "future masters of the country."

It was publicly declared that the "new masters of the country" will supposedly manage the "national property" in a more efficient manner and in the interests of the people, thereby increasing the national wealth and prosperity of the Armenian nation. However, exactly the opposite occurred: the positive logic of the national wealth accumulation was 
gradually pushed out and was eventually replaced by the negative logic of reproduction of new risks and forms of economic alienation. At first the new owners did not know how to deal with the property that they had acquired so easily (if we disregard the re-sale of the "robbed" property and other forms of economic fraud). In those years the earlier concocted myth of the "people's capitalism" also started to fade away. It, too, had its hidden rationale. Promoting the idea of voucher privatization, the newly emerged elite were confident that both they and their shady partners would be given an opportunity to purchase most vouchers from the population at the lowest prices. As a result, instead of privatization the property grab was undertaken by the new elite in Armenia as well as in other post-Soviet countries. Instead of giving rise to a numerous class of small and medium entrepreneurs, those transformations led the emergence of small and medium entrepreneurship as a form of completely dependent economic activities. There are all grounds to contend that fusion of the nomenclature-oligarchic capital and the State in Armenia is a main source of "prosperity" for big businesses, monopolization of the economic life as well as alienation of small and medium entrepreneurs from the socioeconomic life.

While discussing the Armenia's social structure marginalization issues, we should bear in mind the above conclusion that the marginalization has been brought about first of all by the dramatic changes effected in the relations of ownership, distribution, exchange and consumption (see Harutyunyan, 2003). The Armenian model of social stratification is characterized today by a thin layer of the Armenian wealthy, by a small middle class and by a group at the very bottom of the social structure, the lumpen underclass that constitutes the basic stratum and is completely alienated from the Armenian society. It should be stressed here that the crucial factor throughout the structural division is an unprecedented growth in social inequality and injustice, the manifestations of which are observed in disastrous decline in the living standards and in an inexorable slide down of numerous social positions or, which is the same thing, in widespread and pervasive poverty. Figuratively speaking, two Armenias emerged in this country, which differ from one another as the "field of wonders" and the "field of tears" do. The social structure of the nation experiences cracks and fissures. People cringed, huddled together in their families and small groups and have been moving away from one another very much like the gas atoms scatter in the void. The nation that in the recent past was whole and unified starts looking like a pile of sand.

The rich started perceiving themselves as special, "new" people and took the name "new Armenians." But "ethnicization" of social groups takes places not only in a top-down fashion but also in a bottom-up one. Living together in poverty gives rise to the consciousness that is close to an ethnic one.

While discussing the issues of fragmentedness of social structures, this study justifies a social class approach. At the same time, it should be noted that the currently disengaged working class in Armenia can be regarded as a social class from the perspective of the present-day interpretations. The same holds true for the middle class. In contrast to the "patriotic" appeal of the Ter-Petrossian regime elite to create a middle class in Armenia, in reality the middle class not only failed to consolidate but was also thrown into the abyss of social obscu- 
rity. Sociological studies demonstrate that in case of Armenia we deal not so much with a class structure as with a breakup of the Armenian society into the "well-fed and the hungry". The process is not over yet; however, there is no doubt whatsoever that in the recent future that will be become an irrefutable social fact. No doubt, that will become a main social contradiction in the Armenian society and, thus, a main source of mass-scale alienation.

This study has registered a quite wellknown fact that, firstly, due to the shock therapy policies in Armenia a social group of the destitute people, whose numbers have reached disastrous proportions and that has become the most numerous element of a marginalized social structure. Secondly, an important specific feature of yesterday's and today's poverty is that it becomes protracted, continuing poverty for working people. It is a grave social problem, which is not necessarily related to personal qualities required by work and professional ethics. It is not a far-fetched assertion: the salaries of over a half of people employed in science, education and other spheres are lower than the living wage. Thirdly, there is a large number of social groups in Armenia that have de facto been driven not only from the labor market but also from politics, economy and cultural life. It is this expulsion and the existence of the groups of "cast-offs" is one of the sociological mechanisms creating permanent mass-scale alienation from public life. Consequently, a vicious sphere of poverty and alienation (which are essentially the same thing) has emerged in the Armenian society. Parents who are indigent and alienated from social and national life, as a rule reproduce potentially indigent children who are alienated from fullfledged childhood. Its clear manifestation is the growth of "social orphanhood" or forced orphanhood. Fourthly, the social-moral profile of widespread poverty is significantly affected, first of all, extreme weakening of kinship, undesirable transformation of kinship values, their reproduction, especially of the mechanisms of mutual aid and solidarity, or rather, their deepening crisis. Ending up on the brink of social degradation, poor people and their children often do not see any source of support and they panic or fall into deep depression or commit violent acts. Our studies show that the "social bottom" of the Armenian society is very dangerous since it is prone to violence. In Armenia, residents of the "social bottom" are a natural resource for the criminal world. The Maidan in Kiev demonstrated that such individuals can also become a resource for political disturbances.

There is no doubt that owing to shock therapy and economic "reforms" Armenia ended up in the worst of all possible situations. Those "reforms" were indeed a disaster and Levon Ter-Petrossian personally and the entire PANM palace clique hold great political responsibility for it. It is not surprising that the reckless project of the PANM "reform" did not consider the designing of mechanisms for prevention of across-the-board impoverishment of the population. The PANM leadership failed not only to put forth a strategic comprehensive development program (including prevention of almost the entire population) but also to take any effective measures to mitigate extreme manifestations of mass impoverishment. That was the consequence of "socio-political callousness" or, to put it in another way, of criminal irresponsibility on the part of the authorities. The PANM "young reformers" did not even make an effort to understand that poverty 
in Armenia is of a totally different type, which had and still has a totally different dynamic than in the Western liberal society towards which they were presumably headed but which, however, they did not know or understand. The present study discusses the structure of poverty in connection with the processes of anomization and marginalization of the Armenian society. Both the overall poverty and marginalization and anomization are regarded as sociological mechanisms for reproduction of socioeconomic alienation.

The results of the analysis of the processes of the overall poverty, marginalization, anomization and alienation allow reaching a brief conclusion. The Armenian society at present is a marginalized and anomic society since it is a society of extreme social inequality. There is a huge rift between officially proclaimed and widely voiced liberal democratic values and norms and the actual behavior of people. Networks of private, informal connections emerged within official institutions in Armenia. In fact those are rather corruption ties, which are based on mutual obligations. Thirdly, those ties are grounded on the patron-client relations known from the feudal epoch, thereby giving rise to the resurgence of ugly feudal mores in the public mind and behavior. Fourthly, the causes of peculiar resurgence of feudalism should be seen in uncertain and blurred boundaries between the public life and the private spheres and in difficulty of even identifying those boundaries. To be more precise, the causes are mutual alienation of public and private life or, in other words, in prevalence of private, group self-interest over public interests. Fifthly, philosophical reflections on those specific relations between public and private spheres lead to the conclusion that power and property and so in- tertwined here that for the most part one cannot be separated from the other (see Harutyunyan, 2014, pp. 532-550).

At the same time, also should be noted the difficulties and problems that have been identified by the present study and that require further examination from the socio-philosophical and sociological perspectives.

Scores of thousands of Armenians in Armenia feel totally isolated or "driven" away from political processes. They contend that big politics is carried out on their behalf but behind their backs and that those who carry it out pursue their own narrow, group interests disregarding the interests, problems and needs of ordinary Armenians. This "silent majority" is extremely skeptical about their potential for affecting the circumstances of their own lives and of the societal situation and the making of very important political decisions. Sometimes one gets an impression that an ordinary Armenian and the society at large can, at best, try to influence but cannot choose, that they can give an advice to the powers that be but cannot make demands and that they can express their opinions but cannot make decisions. It seems that an ordinary Armenian has been deprived of the sense of being a full-fledged citizen, of a real opportunity to employ his political skills and of will power to re-modernize domestic statehood. Armenians en masse feel alienated not only from the political reality but also from its symbols and perceive political institutions as formal structures that have nothing to do with their social needs and emotions. At the same time it should be noted that political alienation has become systemic, i.e. it has encompassed also executive and legislative branches of power as well as main political parties and non-governmental organizations. 
The examination of the phenomenon of general alienation leads to an important conclusion that it is the powers that be, nomenclature bureaucracy and the business elite that has merged with hem are the main cause of and a driving force behind systemic alienation. It reflects the logic of total alienation of power as well as of alienation of the Armenian society from the powers that be, with the principal specific feature being the concentration of main levers of power in the ruling clique, corrupted bureaucratic apparatus and oligarchic groups that have merged with it. The political class in Armenia retained only one responsibility, viz. to rule the country without any control. The political class degenerated into a self-sufficient force that serves only its group interests. It has essentially become a supreme actor in its own closed little world, which is alienated from the rest of the nation.

The conceptual framework of alienation that is used in the present study makes it possible to identify principal forms of political alienation and their specifics. In my view, the tendencies of political parties' alienation and of Armenian society's disunity are interconnected. It means that political parties have so far failed to establish themselves as a unifying nationwide force. "We have a multi-party system but we do not have parties." In other words, Armenian political parties have not been established yet as universal "social mediators" between the Armenian statehood and the Armenian nation that would help various social groups to express and defend their own interests. As a result, political interests of various social groups are not expressed and represented by political parties. In that respect the issue of adequate identification and description of cracks and fissures in the mechanisms of representation and delegation of interests of social groups and classes of the Armenian society has become urgent and requires intensive efforts of Armenian political scientists, philosophers and sociologists. The analysis leads to an idea that distrust that the majority of the Armenian population has of political parties is a manifestation of mutual alienation between the Armenian society and the political system. The phenomenon of "cartelization" of those parties (i.e. their fusion with State bodies) is also a serious obstacle to adequate operation of political parties. The ruling political party in Armenia remains rather an administrative-political unit than political party per se in a classical sense. The only reason why bureaucrats and businessmen join that political party is that they want to get an opportunity to make use of administrative resources (Derluguian, 2009, pp. 115-116).

The fact of growing alienation of the party bureaucracy from the rank-and-file members causes serious concern. It follows then that the party bureaucracy has also become an "anti-social" self-oriented force that serves its own group interests. The power of the political party leader is limitless. He cannot be removed from office and if he resigns, he does that solely of his own accord. Besides, the bureaucratization of political parties manifests itself also in the fact that candidates running for the parliament are not selected by people of Armenia but are appointed by political parties. The candidates are aware that they actually do not represent people and that they essentially do not have the legitimacy, which is necessary for counteracting the party bureaucracy. It proves once again the narrow boundaries for the constituency in the "managed democracy" in Armenia. 
The approach taken in the present study to interpretation of the essence of political alienation, its sources and forms makes possible an adequate analysis also of such a phenomenon as alienation in the practice of functioning of the Armenian electoral system. Undoubtedly, elections in Armenia are a specific way to express will. Its political formula is "we have elected instead of you and you, voters, must merely confirm this." The analysis of the political practice of the elections leads to a conclusion that under the guise of formal acceptance of ordinary Armenians' electoral rights, the clan-oligarchic system in fact confirms their self-alienation from their own right to vote or, in other words, from the expression of their will and from the electoral process.

Omnipotent Armenian bureaucracy created not only corruption but also filled bureaucratic institutions with informal networks of personal ties and interests. During his first term in office the Armenian President Serzh Sargsian did not manage to transform the Armenian bureaucracy: the latter has been and still is a holder of selfish and mercenary political ambitions. Political corruption is an Achilles' heel of the Armenia's State apparatus and bureaucracy. Its main forms are public officials engaging in private business using their official position and appointment of representatives of big companies and political parties to top-level positions in public administration.

The conceptual and practical results of the present study are summarized in the following conclusions. First, political corruption reached its final form, when it captured the State. In other words, State power in Armenia has been "privatized" by the country's political class and the oligarchic business elite that has merged with the former. The high-ranking public officials (or, to put it in a different way, the nomenclature bureaucracy) introduces the "rules of the game" (laws, decisions, etc.) in the interest of big businesses in exchange for unlawful and non-transparent services. By bribing public officials, they essentially "buy the State" to create an institutional environment that benefits big businessmen and oligarchs so that they get centralized rent at the expense of the rest of the economy. Thus, powers and administrative resources started to be used with a view of gaining control over natural resources, main financial flows, State and private property and the most influential mass media so as to increase wealth of the "ruling class." Second, the essence of political corruption is its use as a mechanism for redistribution of the resource rent and of social positions not only between the powers that be and the biggest businesses but also between various social groups. Third, political corruption in Armenia also turned into a specific arena for settling accounts by influential groups that constitute the "ruling class." The conflict here focuses primarily on economic and political entities rather than on the essence of corruption. Finally, in a political sense, corruption is, in my view, one of the core elements of the peculiar informal social "contract" existing in Armenia.

While discussing Armenia's anti-corruption program, it is not difficult to notice that it completely ignores the European countries' lessons drawn from the experience in fighting corruption. The experience indicates that Western countries succeeded in lowering the scale of corruption by having changed the attitude of civil society and its institutions and various social groups to that two-faced Janus. A change in societal attitudes was a key factor in energizing 
the fight against corruption in various countries. At the same time, one of the lessons drawn from the Western experience is that Armenia's anticorruption program ignored personal interest and the necessity of institutionalizing it. In the society where State regulates market economy and developed institutions of participatory democracy and where institutions of property have been clearly set and protected and the socioeconomic policy, which is significant for the society, is carried out, the motives of justice and personal gain can play a considerable role in the fight against corruption. After all, effectiveness of the fight against corruption is predicated on the state of the Armenian society and on the extent of citizens' solidarity in that targeted fight. Conversely, when the State is entirely alienated from the society and opposed to it, the personal interest, as a rule, acts against the State; hence, all efforts in the fight against corruption are futile.

Following up on the philosophical analysis of the political alienation forms in Armenia and of their consequences, the present study pays special attention to the national specifics. There is no doubt that the situation of nationwide alienation is manifested in this country in a specific way. It is in fact alienation not only from the ruling clique in Armenia, or, in other words, from the ruling class, business elite, political parties, politics and non-governmental organizations, but also from the national reality and the national problems in general. Systemic distrust has become a sole internal and external reality of life of an average Armenian. Growing feelings of alienation are not infrequently accompanied by more acutely felt feeling of powerlessness. This is powerlessness of an individual and the society to do away with the phenomena that create discontent and criticisms. A sad paradox is that the former Armenian President Robert Kocharian too speaks about pervasive feelings of hopelessness and despair and profound distrust concerning the country's prospects. What a glaring example of political hypocrisy!

A combination of emotions of political alienation with the feeling of powerlessness produced various versions of the internal structure and behavior of the individual. For example, a type of personality emerged that had an extremely critical stance vis-à-vis the main political institutions of Armenia but in its practical daily routine has remained conformist.

Trivial everyday pragmatism and even cynicism could coexist with a high degree of discontent.

Other types of alienated person have also emerged. Thus, in case of a person feeling hopeless the alienation is often manifested in stresses, neuroses and in a desire to seek oblivion with the help of alcohol and drugs. Or else inner social dissatisfaction easily mutates into irritation and political rancor, which owing to a value vacuum are shifted and transferred onto any politicians and political parties that have been assigned the role of scapegoats under the influence of public opinion. Therefore a conclusion is drawn that numerous manifestations of alienation indicate a tendency of a spreading feeling of political dissatisfaction. Typical states of discontent and alienation are determined primarily by emotions which are quite unstable and which tend to fluctuate, to rise and fall rapidly and to dash from side to side.

The problem is aggravated by the fact that even though they are displeased and disappointed with the prevalent, first of all liberal, forms of politics, ordinary Armenians in the overwhelming majority of cases have not 
yet acquired a truly alternative ideology of the political action program. Often they do not have an alternative model of future evolution of the Armenian society. Armenians have lost faith in government programs, while new nationwide programs are not offered to them.

At present serious attempts are made to understand what kinds of persons ordinary Armenians are, why they are extremely skeptical or take an ironic approach to the idea of making the Armenian society healthier. And everyone is persistently puzzled as to what should be done. This, however, proves insufficient. We almost never take the trouble to critically analyze the socio-political practice, which prevents the individual to become a citizen of his country. We should not forget that ordinary people's ideas about powers that be have been influenced by quite a dramatic experience of the last 20 years of undermining and weakening people's faith in the law and democratic values and by exacerbation of feelings of social and legal insecurity experienced by many people. To ignore these facts for the sake of following the philosophical fashion is at least short-sighted.

The creation of a substantive conceptual framework for the development of Armenia requires a fresh approach to the modernization theory through its projection onto the country's existing problems. To accomplish this task we need to make conscious and consistent efforts to use the achievement of that theory for designing a national strategy of modernization. In other words, we need to have the modernization theory localized to specific development problems of Armenia. At the same time it is impossible to entirely ignore theoretical philosophical research.

We are clearly aware that a realistic modernization project can adjust and redirect many things. It, however, cannot and, more impor- tantly, must not strive to recreate the Armenian society following unrealistic illusions. One such attempt has already been made and has been paid for dearly. Enough is enough. Therefore, much attention is paid in the monograph to comprehensive democratization of Armenia's State-legal and political systems. To do that requires, firstly, strengthening of the system of checks and balances between the branches of government. Given the significant powers of the Armenian President, the gap between the branches of government, constitutional norms and the societal practice still remains and is growing thereby placing obstacles in the way of democratization of the system of power. Secondly, it is necessary to expand dramatically powers of the representative bodies of power. Thirdly, it is necessary to modernize the structure of the executive branch of power in Armenia with a view to securing active participation of political parties and civil society institutions (first of all of the Public Council) in the process of preparing decisions that are important for the State. Fourthly, the principle of the supremacy of law should be applied consistently. The principle requires that power and property be separated as well as the executive power and the control over it and that a civic mechanism for ensuring transparency be set up and its operation be ensured through legislation. Fifthly, a new model of public administration in Armenia should be developed, which will be grounded in cooperation between the branches of government, business elite, political parties, academic and ministerial science and non-governmental organizations. Sixthly, a relatively low level in implementation of the free competition principle prevents mitigation of alienation. The mechanisms for systemic and practical implementation of the free competi- 
tion principle should be improved. Competition is a source of life and eternal youth of any political organism and a driving force for the latter's development and for a creative response to challenges.

As this study has demonstrated, at present a new perception of justice and of "just development" are more in line with the interests of the majority of people in Armenia. It is grounded in the following formula or model of justice: effective social protection to the poor, State support to active and enterprising citizens and law and responsibility to the rich.

Finally, clarification of the conceptual principle of assessing the justice issue, an independent and non-governmental monitoring of social injustices and the creation of the "social lift" systems are important and topical. The Armenian nation and statehood need the hopeful prospects of social and political justice. In its new perception, justice must become one of the fundamental values and mechanisms for the national-democratic program of Armenia's modernization. The establishment of the social mechanisms based on the principles of a new interpretation of social justice will give an opportunity not only to overcome social alienation but also to bring back legitimacy to the State system and authorities in Armenia as well as to change the very approach to the solution of many problems, first of all the problem of poverty and social inequality.

The consistent implementation of the social justice principles and the strengthening of positive social guidelines in the Armenian society will allow a more effective carrying out of vitally important tasks of preservation of the Armenian nation and of attaining a new quality of the nation.

\section{REFERENCES}

Derluguian, G. (2009). Krizis neovotchinnogo pravleniya (The Crisis of Neo-Patrimonial Management, in Russian). Armyanskii transit. Problemy i perspektivy sotsial'noi transformatsii (Armenian Transit. Problems and Prospects of Social Transformation), 115116.

Harutyunyan, M. (2003). Alienated Society: from Diagnosis to Action. Armenian Society in Transition, 109-119.

Harutyunyan, M. A. (2014). Ardi hay hasarakut'yuny' \& o'tarvac' gitakcut'yan pilisopayut'yuny' (Modern Armenian Society and Philosophy of Alienated Consciousness, in Armenian). Yerevan: Nairi. 